\section{The Romanesque Portal of the abbey-church of Cluny: study of polychromy}

\author{
Stéphanie Castandet, ${ }^{1,2,3}$ \\ Juliette Rollier-Hanselmann ${ }^{1}$
}

'Equipe Gunzo, Institut Image UMR 5158 CNRS, Arts et Métiers ParisTech, Cluny; ${ }^{2}$ Laboratoire Archéométrie et

Archéologie, UMR 5138 CNRS, Université

Lumière Lyon 2, Lyon; ${ }^{3}$ Institut de

Recherche sur les Archéomatériaux,

Centre de Recherche en Physique

Appliquée à l'Archéologie, UMR CNRS

5060, Université Bordeaux 3, Bordeaux,

France

\section{Abstract}

The Romanesque abbey of Cluny was almost entirely destroyed after the French Revolution. As part of the Cluny 2010 initiative (the commemoration of the $1100^{\text {th }}$ anniversary of its foundation), the Gunzo project leads the research and promotion of the heritage of Cluny thanks to digital technologies and virtual reality. This interdisciplinary team is working on the creation of a digital model of the Cluny abbey according to the latest scientific research, including the archaeological excavations and the study of the documentary sources. Samples of polychromes and gildings were collected from selected lapidary fragments which are representative of different parts from the Romanesque Portal (jambs, lintel, tympanum and archivolts). Pigments and gildings were analysed using scanning electron microscopy (SEM), energy-dispersive Xray spectrometry (EDS) and micro-Raman spectrometry. The physicochemical analyses point up the use of relatively expensive materials, such as gold leaves, lapis lazuli or cinnabar. Moreover, some blackish layers were identified as altered leaves of tin. The palette and abundance of metallic leaves should reflect the prestige of the abbots of Cluny.

\section{Introduction}

The year 2010 marks the $1100^{\text {th }}$ anniversary of foundation of the greatest Romanesque abbey of Europe. Cluny - located in Burgundy, France - was synonymous with power. Put under the supervision of Rome, it was at the head of a vast network through all Europe. Its church, called Major Ecclesia, was the greatest of Christendom until the reconstruction of StPeter's Basilica of Rome in the $15^{\text {th }}$ century. It had atypical attributes: $187 \mathrm{~m}$ in length, about $40 \mathrm{~m}$ in elevation under the dome of the great transept (the highest vault ever built), five naves, two transepts, 301 windows, five church towers. Unfortunately, it was almost entirely destroyed after the French Revolution (only eight percent is left undestroyed).

This research is related to a project of promotion of Cluny's heritage: Cluny 2010, European abbey of knowledge. Gunzo, an interdisciplinary team (engineers, art historians, archeologists, restorers among others), named after the abbey's legendary designer, leads the research thanks to digital technologies and virtual reality. The team is working on the creation of a new digital model of Cluny abbey based on the latest scientific research, including archaeological excavations, the study of documentary sources and the examination and analysis of decorations (paintings and stained glass windows).

Initially we were focused on the polychromy of the Romanesque entrance (1115-1120) of Cluny III. The immense portal (around $16.60 \mathrm{~m}$ high) represented a Majestas domini. The Christ enthroned in a glory is attended by angels, cherubim and the symbols of the four Evangelists on the tympanum, while, in the archivolts above, the Eternal Father, attended by the twenty-four elders and a circle of angelic beings, constitute the celestial Court of Heaven gathered to receive him. In 1810, the portal was blown up with gunpowder and only few mutilated fragments remain. In order to try to reconstitute it and its polychromes, we base our work on the previous results from Conant (1968) and Kleinschmidt (1970) who studied fragments of the 30 s excavations and on new fragments excavated by G. Rollier at the end of the 80 s. The remaining polychromes are sufficient to indicate the predominant colours of most of the decorative and iconographic elements.

\section{Materials and Methods}

About 40 samples of painting were collected from lapidary fragments discovered during archaeological excavations (K.-J. Conant in 1928-1950 and G. Rollier in 1988-89). The selected fragments are representative of different parts of the portal (jambs, lintel, tympanum, and archivolts). Their study provides data about the materials used for decoration (preparatory layers, pigments, metallic leaves) and helps us identify their alterations (significant in the case of a virtual restoration because of the colour changes it can create).

Polished cross-sections of stratigraphic sequences of these samples were prepared and examined under optical and scanning electron microscopes. Chemical analyses were per-
Correspondence: Stéphanie Castandet, Equipe Gunzo, Institute Image UMR 5158 CNRS, Arts et Métiers ParisTech, rue Porte de Paris, 71250 Cluny, France.

Tel/Fax: +33.3.85595367

E-mail: stephanie.castandet@gmail.com

Key words: Cluny, Great Portal, polychromy, gildings.

Citation: Castandet S, Rollier-Hanselmann J, 2013. The Romanesque Portal of the abbeychurch of Cluny: study of polychromy. In: RH Tykot (ed.), Proceedings of the $38^{\text {th }}$ International Symposium on Archaeometry - May $10^{\text {th }}-14^{\text {th }} 2010$, Tampa, Florida. Open Journal of Archaeometry 1:e11.

Ackowledgements: the authors wish to thank the Conseil Régional de Bourgogne which provided funding for this project, the Centre de Recherche en Physique Appliquée à l'Archéologie for the characterisation techniques, and the Musée d'art et d'archéologie of Cluny for the samples.

Presented at the $38^{\text {th }}$ International Symposium on Archaeometry - May $10^{\text {th }}-14^{\text {th }} 2010$, Tampa, Florida.

This work is licensed under a Creative Commons Attribution 3.0 License (by-nc 3.0).

(C) Copyright S. Castandet and J. Rollier-Hanselmann, 2013

Licensee PAGEPress, Italy

Open Journal of Archaeometry 2013; 1:e11

doi:10.4081/arc.2013.e11

formed using energy dispersive X-ray spectrometry coupled with scanning electron microscopy (SEM) (JEOL JSM 6460LV - Oxford INCA 300). Structural analyses were carried out using micro-Raman spectrometry (Renishaw RM 2000), which allowed identifying pigments. The Raman spectra were collected using a laser excitation at $632.8 \mathrm{~nm}$.

\section{Results and Discussion}

\section{Stone and preparation}

It seems that the two types of limestone used to build the Romanesque portal (Blanc et al., 1990) have not kept the colours the same way. In the lower parts, in gray-beige oolitic limestone, more vulnerable to degradations, the coloured elements are often damaged. On the upper parts carved from a creamy-white limestone pisolithic, softer and more porous, the colours are better preserved.

A layer of lead white (Table 1) was generally used as preparation for the pictorial layers. Only the elements belonging to jambs have a yellow ochre preparation (Table 1), and St. Peter's, preserved in Rhode Island (USA), is 
Table 1. Qualitative scanning electron microscopy energy-dispersive X-ray spectrometry and Raman results for determination of the used pigments.

\begin{tabular}{|c|c|c|c|c|}
\hline Colour & Samples (example) & SEM-EDS & Raman & Identification \\
\hline White (preparatory layer) & $\begin{array}{c}\text { Bdx } 14301 \\
\text { Wing of angel, archivolt }\end{array}$ & $\mathrm{Pb},(\mathrm{Cl}, \mathrm{Ca}, \mathrm{Al})$ & Lead white & Lead white \\
\hline White (repaint) & $\begin{array}{c}\text { Bdx } 13360 \\
\text { Atlante, lintel }\end{array}$ & $\mathrm{Ca}, \mathrm{Si}, \mathrm{Al},(\mathrm{Fe}, \mathrm{S})$ & Calcite & Lime wash \\
\hline Yellow (preparatory layer) & $\begin{array}{c}\text { Bdx } 14329 \\
\text { Molding, jamb }\end{array}$ & $\mathrm{Si}, \mathrm{Al}, \mathrm{Fe}, \mathrm{Cu}, \mathrm{Ca}, \mathrm{Pb}, \mathrm{K},(\mathrm{Mg}, \mathrm{Ti}, \mathrm{P})$ & Goethite & Yellow ochre \\
\hline Bright yellow & $\begin{array}{c}\text { Bdx } 14301 \\
\text { Wing of angel, archivolt }\end{array}$ & $\mathrm{Pb}, \mathrm{Sn}, \mathrm{Si}, \mathrm{Ca}, \mathrm{Cu},(\mathrm{Al}, \mathrm{Fe}, \mathrm{Cl})$ & Lead-tin yellow & Lead-tin yellow \\
\hline Blue & $\begin{array}{c}\text { Bdx } 13368 \\
\text { Background, angel, archivolt }\end{array}$ & $\mathrm{Si}, \mathrm{Ca}, \mathrm{Al}, \mathrm{Pb}, \mathrm{Na}, \mathrm{Cu}, \mathrm{P}, \mathrm{K}, \mathrm{Fe}, \mathrm{S}, \mathrm{Mg},(\mathrm{Cl})$ & Lazurite & Lapis lazuli \\
\hline Blue (repaint) & $\begin{array}{c}\text { Bdx } 13368 \\
\text { Background, angel, archivolt }\end{array}$ & $\mathrm{Cu}, \mathrm{Si}, \mathrm{Ca}, \mathrm{Fe}, \mathrm{Al}, \mathrm{P},(\mathrm{Cl}, \mathrm{Mg}, \mathrm{K}, \mathrm{S}, \mathrm{Ti})$ & Azurite & Azurite \\
\hline Red & $\begin{array}{c}\text { Bdx } 13362 \\
\text { Halo of angel, archivolt }\end{array}$ & $\mathrm{Hg}, \mathrm{S},(\mathrm{Al}, \mathrm{Fe}, \mathrm{Ca})$ & Vermilion & Vermilion \\
\hline Orange & $\begin{array}{c}\text { Bdx } 13340 \\
\text { Acanthus, lintel }\end{array}$ & $\mathrm{Pb}, \mathrm{Si},(\mathrm{Al}, \mathrm{Ca})$ & Red lead & Red lead \\
\hline Green & $\begin{array}{c}\text { Bdx } 14301 \\
\text { Wing of angel, archivolts }\end{array}$ & $\mathrm{Cu}, \mathrm{Ca}, \mathrm{Si}, \mathrm{Al},(\mathrm{Fe}, \mathrm{Cl}, \mathrm{K})$ & & $?$ \\
\hline Bright green & $\begin{array}{c}\text { Bdx } 13329 \\
\text { Molding, jamb }\end{array}$ & $\mathrm{Pb}, \mathrm{Sn}, \mathrm{Cu}, \mathrm{Ca}, \mathrm{Si},(\mathrm{Al}, \mathrm{Fe}, \mathrm{Cl})$ & Lead-tin yellow & $\begin{array}{l}\text { Lead-tin yellow in copper } \\
\text { resinate? }\end{array}$ \\
\hline Black & $\begin{array}{c}\text { Bdx } 13353- \\
\text { Mustache of elder, archivolt }\end{array}$ & Carbon black & Carbon black & \\
\hline Rose (flesh tone) & $\begin{array}{c}\text { Bdx } 13333 \\
\text { Sleeping soldier, lintel }\end{array}$ & $\mathrm{Pb}, \mathrm{Hg}, \mathrm{Si}, \mathrm{Fe}, \mathrm{Al}, \mathrm{Ca},(\mathrm{S}, \mathrm{K}, \mathrm{Cl}, \mathrm{Mg}) \quad \mathrm{L}$ & Lead white and vermil & n Lead white and vermilion \\
\hline Grayish & $\begin{array}{c}\text { Bdx } 13328 \\
\text { Rosette, jamb }\end{array}$ & $\mathrm{Sn},(\mathrm{Si}, \mathrm{Pb}, \mathrm{Al}, \mathrm{Cl})$ & - & Tin leaf \\
\hline Gold & $\begin{array}{c}\text { Bdx } 13357 \\
\text { Hair of angel, archivolt }\end{array}$ & $\mathrm{Au}, \mathrm{Pb}, \mathrm{Ca},(\mathrm{Al}, \mathrm{Fe})$ & - & Gold leaf \\
\hline
\end{tabular}

composed of lead white mixed with grains of vermilion [analyses carried out at the Conservation Department of the Fogg Art Museum (Cambridge, USA), in 1973].

\section{Palette}

The figures of the tympanum, lintel and archivolts stand out against a blue background. The chemical analyses show the presence of an aluminum and sodium silicate (Table 1). It's the lazurite, identified by Raman, and main component of the lapis lazuli. The latter is on a layer of carbon black mixed with lead white. The lapis lazuli is often put on a layer of carbon black in order to use less of the precious pigment.

Two samples, taken from the background of the lintel, presenting only the layer of lead white mixed with carbon black, were visually blue. Is it a deliberate optical effect, or is it due to the sampling?

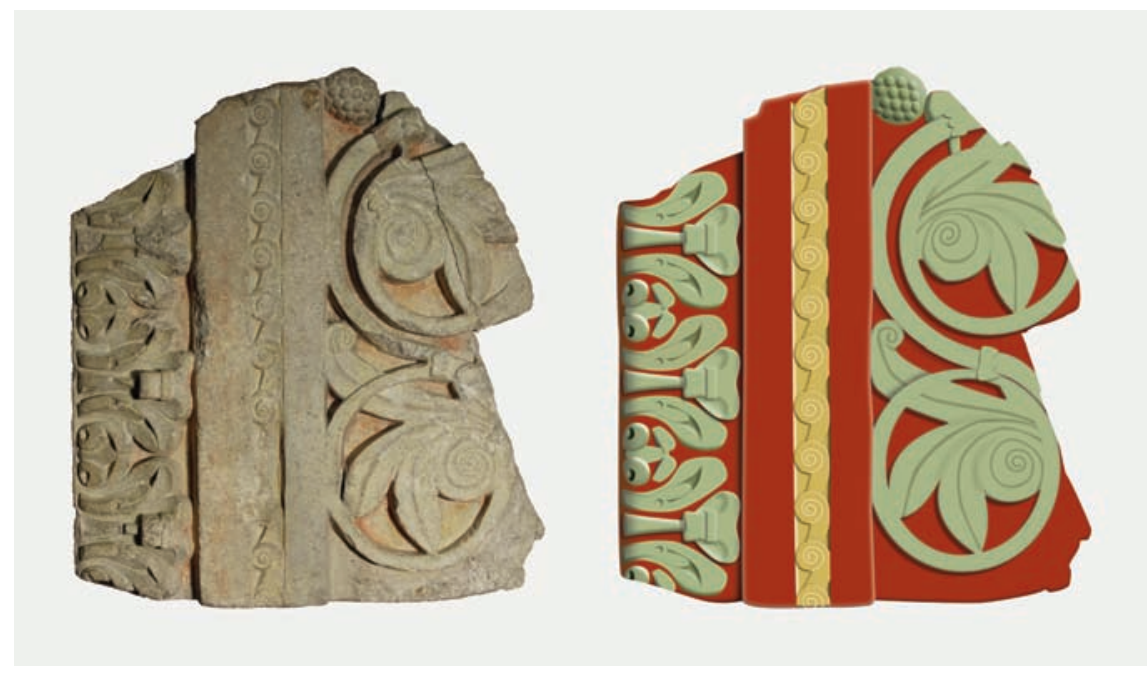

Figure 1. Fragment of the first jamb (limestone, $40 \times 35 \mathrm{~cm}$ ) and coloured restitution. Reproduced with permission of S. Castandet and A. Mazuir, Arts et Métiers ParisTech, Cluny, France. 
The red and green, juxtaposed, are widely used in the architectural framework and decorative carving (Figure 1). This combination of colours is very common in the Middle Ages.

Most of the red samples correspond to vermilion applied on a layer of red lead (Table 1); these pigments are sometimes mixed. The red ochre is seldom used, at least in the context of this study (remaining and studied fragments); on the other hand, this pigment is more abundant on the occidental Gothic portal.

The green layers are made of a copper-based matrix containing lead-tin yellow (Table 1).

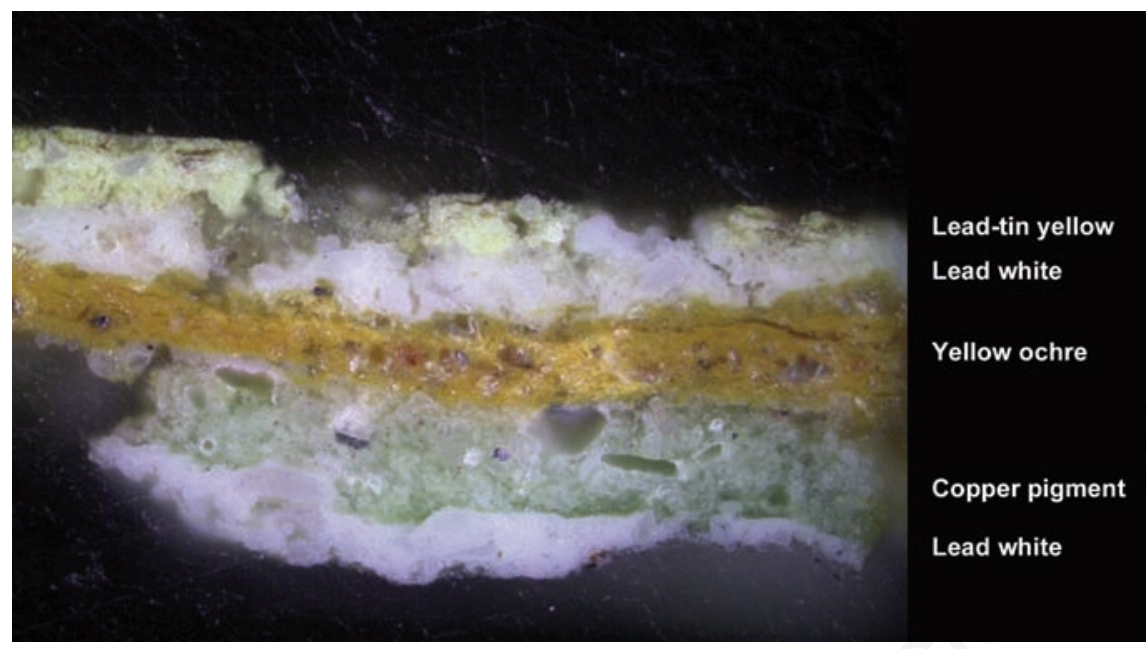

Figure 2. Stratigraphic section of a sample from a fragment of angel wing belonging to the archivolts (Bdx 14301). The green of the first coloured layer consists of a copperbased pigment, while the yellow-green of the upper layer is a repaint of lead-tin yellow (magnification x200). Reproduced with permission of S. Castandet, Centre de Recherche en Physique appliquée à l'Archéologie, Bordeaux, France.

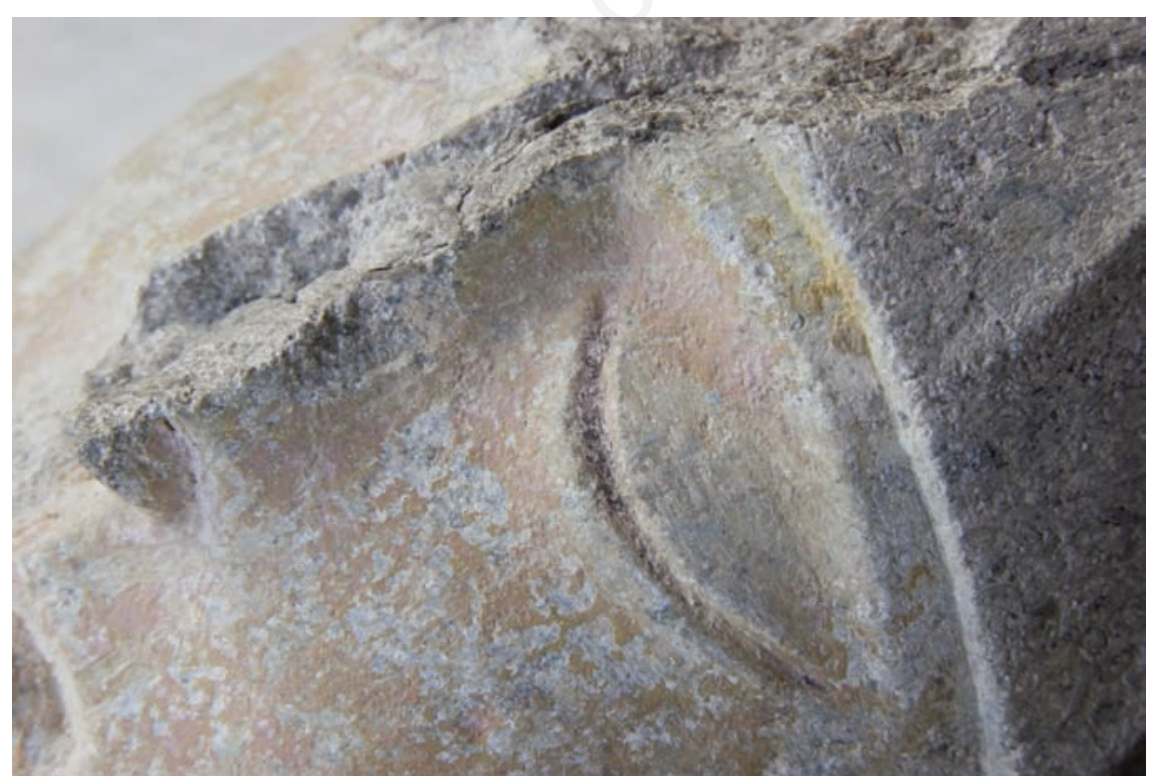

Figure 3. Head of the sleeping soldier (limestone, $16 \times 9 \mathrm{~cm}$ ) coming from the lintel. Reproduced with permission of S. Castandet. layer covered by three coloured layers (Figure 2); the latter consists of lead-tin yellow, which tends to support the hypothesis of a Gothic repaint. The green layer, probably original, consists of a green copper pigment (presence of copper oxide) that the spectrometry Raman had not permitted to identify.

The flesh tones are a mixture of lead white and vermilion (Table 1) as illustrate the almost entirely polychrome sleeping soldier's head (presumed scene of the Holy Women at the Tomb on the left of the lintel) (Figure 3) and the coloured remains of Saint Peter's face, formerly located in the upper part of the Romanesque facade.

A black border, more or less pronounced, highlights eyes, beards and mustaches of faces (Figure 3). The obtained Raman spectrum shows the two main peaks at $1300 \mathrm{~cm}^{-1}$ and $1550 \mathrm{~cm}^{-1}$ characteristics of carbon black.

\section{Gildings}

The brilliance of colours was reinforced by the abundant use of gilding (Figure 4), located around the Christ (halo, mandorla and clouds of angels), and on the lintel (haloes of apostles) or on the archivolts (haloes and hairs of angels, rosettes). The portal includes two kinds of metallic decoration: gold and tin leaves (Table 1). The chemical analyses highlight certain blackish layers corresponding to altered leaves of tin (Figure 5). We cannot say if the tin leaves were employed in imitation of silver or gold. In the case of gold imitation, the Benedictine monk Theophilus gives a recipe of coloured varnish in order to gild tin (Théophile, 1996). We think tin was used as gold substitute because the fragments of the mandorla are gilded either gold or tin and the Christ's halo is covered with tin while all other halos are covered with gold leaves.

\section{Repaints}

Different repaints have been highlighted such as the vermilion on the gilded rosettes of the archivolts, the azurite - less costly - covering the lapis lazuli or the green containing the leadtin yellow. Several samples have two pictorial medieval layers, one, probably Romanesque, subsisting only on some fragments, and the other, Gothic, with the lead-tin yellow. The Romanesque portal was built in 1115-20, followed by a long period of construction of the narthex. At the time of completion of the Gothic facade in the middle of the $13^{\text {th }}$ century, a restoration of the Romanesque portal probably occurred to dust it and revive its colours. This is reminiscent at the cathedral of Bourges, where a first portal coloured around 1225, was restored thirty years later, at the completion of the portals of the west facade. Subsequently, the brilliant polychromes of the portal of Cluny were covered, probably at two different times, by two relatively thick layers of white lime wash (Table 1). 


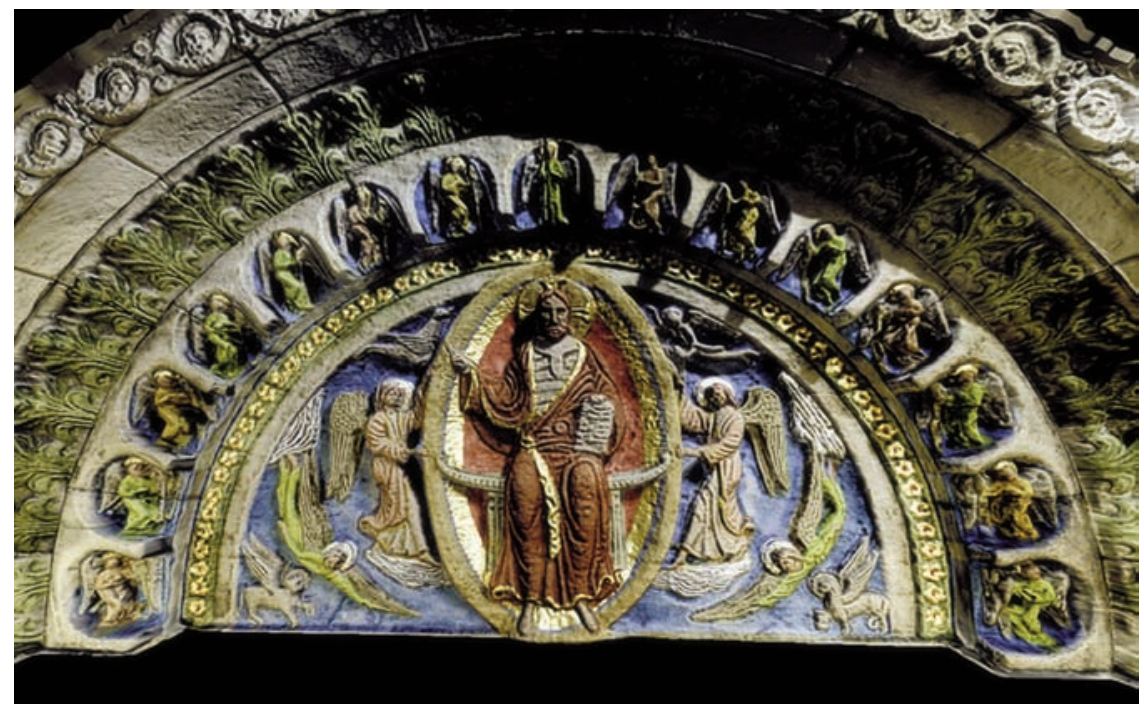

Figure 4. Fisrt try of coloured restitution (with permission of Enodo, Nice and Arts et Métiers ParisTech, Cluny).

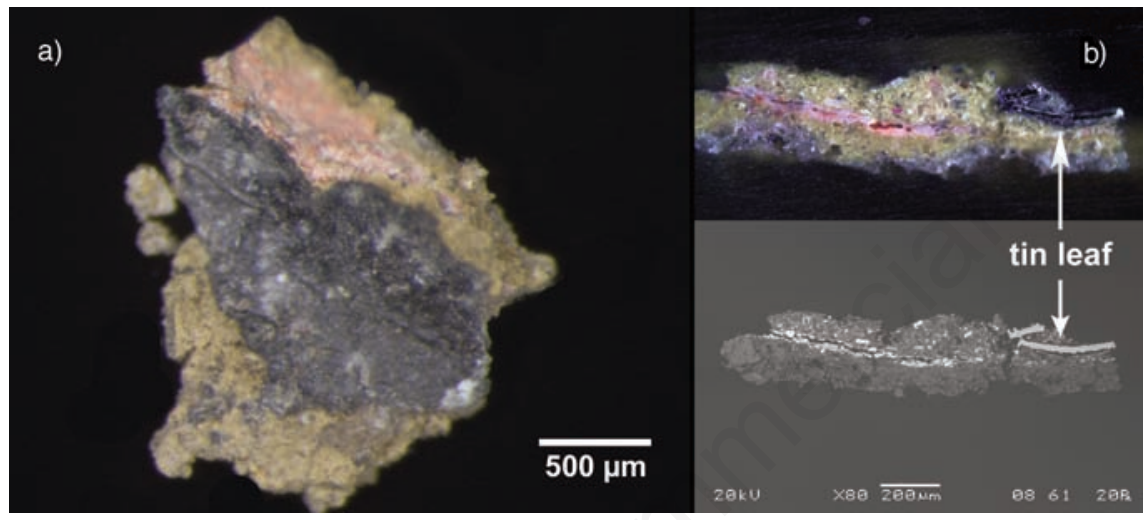

Figure 5. Sample of altered gilding belonging to the rosettes of the jambs (Bdx 13328). Pictures in natural light of this sample (a) and its cross-section and scanning electron microscopy picture of the cross-section (b). Reproduced with permission of S. Castandet, Centre de Recherche en Physique appliquée à l'Archéologie, Bordeaux, France.

\section{Conclusions}

Physicochemical analyses reveal the use of relatively expensive materials, such as gold leaves, lapis lazuli or vermilion and certain blackish layers were identified as altered leaves of tin. The knowledge of the original material is a prerequisite in a virtual restitution.

The analytical results allow a first attempt of coloured restitution of the Great Portal of Cluny (Figure 4). The repaints such as azurite and the lead tin yellow indicate at least two polychrome phases.

The history, the restoration and the analytical results will be gathered in a database associated with the 3D virtual restitution.

\section{References}

Blanc A, Lorenz C, Salvèque JD, 1990. [Les différentes carrières exploitées lors de la construction de Cluny III]. [Proc. in French]. [Actes du colloque Le gouvernement de Hugues de Semur, 1988, Cluny, France]. Musée Ochier ed., Cluny, pp $335-41$.

Conant KJ, 1968. [Cluny. Les églises et la maison du chef d'ordre]. [Book in French]. The Medieval Academy of America ed., Cambridge, Massachussetts.

Kleinschmidt H, 1970. Notes on the polychromy of the Great Portal at Cluny. Speculum 45:36-9.

Kühn H, 1963. Lead-tin yellow. Stud Conserv 13:7-33.

Théophile M, 1996. [Essai sur divers arts]. [Book in French]. Laget, Nogent Le Roi. 